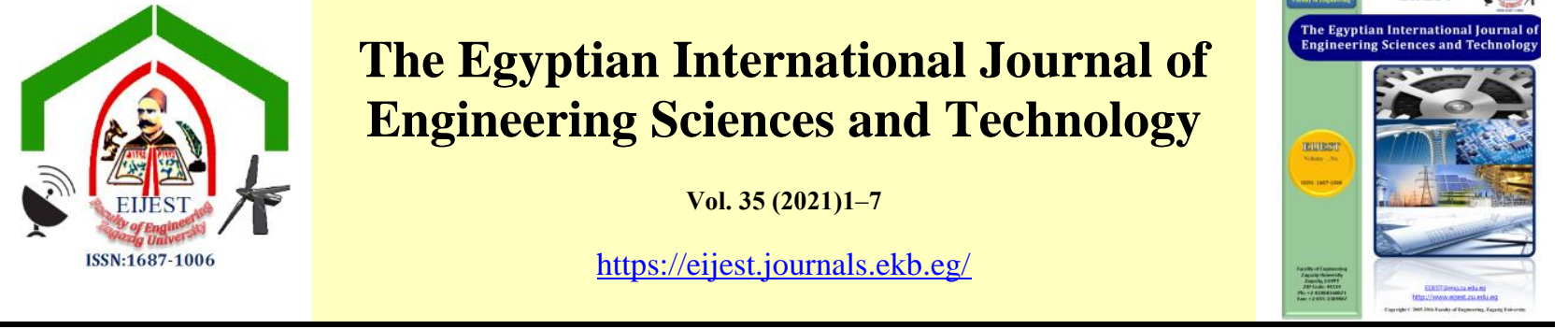

\title{
The Difference Between The Concept Of Space And Of Place In Urban Science
}

\author{
Ahmad Al-Menshawy a, Ahella El-Sieedy b*, Tarek Abuzekry c \\ ${ }^{a}$ Associate Professor; Dept. of Arch.; Faculty of Eng.; Zaqaziq University; Egypt \\ ${ }^{b}$ Master of Science Candidate; Dept. of Arch.; Faculty of Eng.; Zaqaziq University; Egypt \\ ${ }^{c}$ Prof. of Urban And Regional Plng.; Dept. of Arch.; Faculty of Eng.; Zaqaziq University; Egypt
}

\begin{tabular}{l}
\hline A R T I C L E I N F O \\
\hline Keywords: \\
Space \\
Place \\
Urban space \\
The interaction between \\
users.
\end{tabular}

A B S T R A C T

The aim of this paper is to clarify the differences between the concepts of space and of place in urban science. The importance of this distinction stems from the common confusion in using and in mixing the meaning of both concepts in the literature. The research adopts an analytical theoretical review methodology to reach this clarification in different sciences. Moreover, studying the factors that form the place, would help to understand the difference in meaning between them in urban field. The research consists of three main parts. The first part discusses linguistically the space in various disciplines. The second part deals with the concept of place, and its connotations in various fields of knowledge. Then, in the third part the paper delineate the differences between the two concepts. The research comes up with a clear distinction of both concepts in the urban field, and presents them in a form of a comparative table. This comparison is based on differences among the two concepts in various aspects like in activities, in components, and even in meaning itself. It concludes with a discussion to their interplay in changing our urban environment over time.

\section{Introduction}

There is a clear distinction in the field of geography and of social sciences between space and place. In geography, the concept of space is used to determine the political boundaries, the resources and potentials, and the wealth of a specific area [11]. Furthermore, the concept of place is used to determine the ages that have passed on this area [12]. The social and human sciences use the concept of space to understand the impact of the physical environment on human beings. While the concept of place is used to study the social behavior of individuals and groups [9]. In addition to considering the main importance of human existence in his "place" in identity formation, and in sense of belonging. That sense of belonging varies according to the surrounding circumstances and factors [8].

In urban field, the place-makers have differentiated the concept of space and place to explain the concept of placemaking [25]. However, Urban scholars have used geography, social and environmental sciences to differentiate between the concept of space and place.[7]

\section{Research Problem}

Despite the clear definition of both concepts in urban field, we some-times find a confusion in use between the two terms. Examples are many. Some scholars use both of them inter-changeably. For example, UN- Habitat defined the public space as "all 
public- owned or public-used, free, and non-profit places including streets, open spaces, and public utilities" [35]

- In the book "Street As Public Space \& Drivers Of Urban Prosperity" public space is defined as "Public space with residential houses, commercial buildings and other structures on one or each side, therefore, has social and economic functions that are integral to urban life". The author used the concept of "public space" when he talked about the process of street planning and the measurements and the area suitable for them. And he used the same concept also when he talked about the streets that are used for different activities. [34]

- The book "Public Space" [35] the author defines public space as "Public places are all places publicly owned or of public use, accessible and enjoyable by all for free and without profit motive". He used the concept of "public space" when he was talking about the social activities that are practiced in them.

- In the research "Collective Culture \& Urban Public Space" [4] the researcher used the concept of "urban public space" to discuss the cultural aspect.

- In the dissertation titled "Strategies for developing urban public spaces," the researcher defined urban public spaces as " an important component of any urban fabric because it embraces the various activities of the population". [18]

- In the thesis titled "Renegotiating Public Space" the researcher used the concept of "public space" to study the quality of life elements, which he linked to citizen participation and public interaction. [14]

- In the thesis titled "Study of characteristics of urban public open spaces based on social interaction" the researcher used the concept of "public space" to discuss social interactions and socio-economic characteristics. [29]

\section{Research methodology}

The research methodology follows the principles of an theoretical analytical inductive approach. It sheds light on all uses of "space" as a concept in different sciences as well as of "place'. The paper will try to clarify the causes of confusion between them and to study the factors that influence the formation of places. The aim of that is to delineate the meaning of both concepts in urban field, as well as clarify the importance of using both of them as well. Consequently, the concepts of place and space are compared in terms of components and the of types of activities. In addition to identify the measures of their success in performing their roles. The paper will discuss their relationships to the environment and time as well.

\section{Space:}

\subsection{Linguistic Definition of Space.}

French-derived the term "space" from Latin term "Espace". However, the English derived the term "space" from the Latin word "Spatuim", which means the unlimited extension that contains the partial specified extensions. While the Greek used the term "Topos" which means the location.[7]

The concept of space means continuous vacuum or empty area. So, the gap between the sun and the infinite moon can be called space. On other hand, space is defined as an empty land or an area as it is unoccupied with dimensions of length, of width and of depth. It may be also imply a relative direction. Space may have dimensions and determinants that limit it through physical elements such as trees, fences, the sky, buildings, and others. Space may be devoid of determinants such as desert or cosmic space and so on. [15]

\subsection{The concept of space in different sciences}

Space is an abstract term, used for the analysis and study of a certain phenomenon. In environmental sciences, it is an abstract area with equal and consistent characteristics. [23] For example, a perfectly homogeneous area, to study a phenomenon as trend identification, modeling, analysis, etc. Using space as an abstract term will contribute to determining the approximation idea by studying the proximity or distance of the elements developed for determining space, known as distances.[5]

Helen, in her book "Geography Inner's the World (1992)", divided the space into three types, absolute, geographical, and relative space. They are defined as:

\subsubsection{Absolute space:}

The German philosopher Immanuel Kant (1770) defined it as a space that contained an empirical, experimental, or physical entity and could be divided into smaller spaces. For example, the city is an 
absolute space that is divided into smaller spaces, and so on.

\subsubsection{Geographic Space:}

Divided into three types: "Real Space", "Phase Space", and "Order Space. The Real Space is a geographic space reflected through maps, remote sensing images, and so on. Whereas, the phased space is a space described through the geographic system's time series, to know the geographical development of different ages. While the order space is linked to the phase space and is defined through the hierarchical data system according to ranking.

\subsubsection{Relative space:}

It is a space that is time-bound, and its vision is adopted at certain times, whether morning, evening or peak time in its use. The relative space is the one in front of Hussein, the space in front of St. Peter's Church, and the space of the feelings of the pilgrims in Mina. The space of Mina is just an empty area throughout the months of the year, except in the month of Dhu Al-Hajj (hajj season) and this space becomes a place because all the pilgrims meet to hold hajj, as described in the form, see Fig 1. [11]

In urban design, the idea of using space as a term to shape a specific area through points, lines, and curves will become a reality. The people will realize it through development, construction, and reconstruction processes. This type of operation is the basic tool on which planners and architects rely.[25]

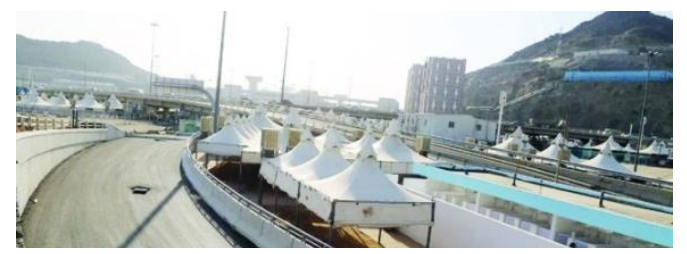

Fig 1.a. Mina is just a space throughout the months of the year, except in the month of Dhu Al-Hajj .

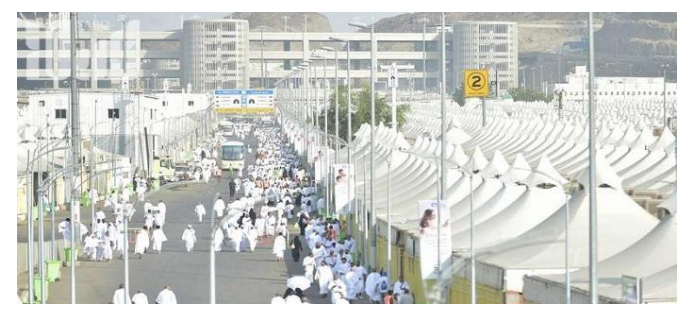

Fig 1.b. Mina is becomes a place because all the pilgrims meet to hold hajj.

Fig 1. Mina is an example of relative space

\section{Place}

\subsection{Place definition}

The word place is derived from the Latin word "Loc", which means the place or the site. While the concept of the place had a philosophical dimension in Greek [2] Plato (1937) was the first to use it, he considered it to be a container of things. Aristotle (1952) considered the place to be composed of things, such as the elements, the images, the motions, and the time. This made the place "a content not a substance", so assuming the existence of the object to determine the place it contains.[6]

\subsection{The concept of place in different fields of knowledge}

The concept of the place is linked to the human experience. The difference in experience creates different places. For example, real places are derived from spatial or physical experiences. While fairy places rely on mental, hypothetical, spiritual, and emotional expertise[19]. Tuan (1977) states that "The place is a space that is contained with human meanings". He discusses two key concepts: That places are shaped by people and their sense of places.[32]

In geography, the word place is used as an expression of location. The place is defined as the location that refers to an absolute point in space. Besides, it is defined by a set of coordinates and distances that are measurable through other locations. The place is a part of the Earth's surface that cannot be similar to any other surface. It cannot be replaced without changing all its objects and features. Since the American Commission -specialized in Geography in 1965 - requested to change the definition, which then defined as one unit among the other units to which the distribution network is linked. This represents a unique entity with history and meaning as well as embodies the experiences and needs of users. It has the meanings and values that arise from the behavior of users. This contributes to the preservation of the quality of the environment, the improvement of use, the satisfaction, and the attachment of places. As a result, the content of the human sense of place is linked to history and geography too. As the place is the historically inhabited geography. [12]

In sociology, Ibn Khaldoun (1981) is defined place as the surface upon which human life happens. Each place has its own unique character. He 
explained the characteristics of the place to considered when establishing the city in terms of the health of establishing it and its suitability for human life [21]. The sociologist Schumacher (1977) also defined the place as the geographical and architectural context of behavior [16]. So, sociology considered the place to be an expression of its population. As a result, a user's description of the places and their behavior in it allows to express the individual and collective values of the inhabitants and describe their social condition. [9]

Economic sciences defined the place as a product that achieves a surplus of money or profits. In the case that the place does not achieve profits, it is considered space or a place that is neither productive nor useful.[9]

Environmental psychology has taken into consideration different perceptions of the place from the standpoint of physical determinism. Since the environment characteristics have a direct impact on behavior. The impact is achieved by studying the relationship between people and the interactive environment. As the interaction of the environment achieves the social, cultural, and psychological meaning of the place. [8]

The term "psychology of place" considers the place as a product of physical, human, and activity qualities. Also, it is based on the interplay of people and the environment. The place is a combination of physical components such as natural and manufactured elements, non-physical components such as activities, values, meanings, and symbolism. These combinations are associated with the community of the place in a dynamic interactive process and interactions among the people of the place. This leads to developing their sense of belonging and identity. [20]

While the concept of place from the perspective of Schulz (1974) is a set of relationships between user and the environment. Furthermore, to recognize the vital relationships in his environment, to give meaning to the activities in which he exercises, and to determine the nature and identity of the place. This can be achieved through the features of a place that include the environmental and natural characteristics of it. Detailed features of the place give formal privacy, symbolic and sensory meanings [27].

\subsection{Interaction between places and users}

Relph (1976) identified three components of space: Physical properties, activities, meanings. He defined the place as a space bearing human meanings [26]. Angew (1987) studied the relationship between places and human behavior. Besides, the effects of places on economic, social, and cultural processes were drawn. In economic terms, it means the place's role in the global economy. In social terms, it means establishing a place of different social activities, interactions, physical elements, and characteristics. While in cultural terms it means the identity, meanings, and values that the place is reflected in.[1]

The interaction between users and places involved in three dimensions, awareness, behavior, and sense of belonging. Awareness of interaction leads to spatial perception. Behavioral interaction is referred to activities and functional relationships between people and the environment. While the sense of belonging is achieved through the user's sense of satisfaction, which leads to the formation of a strong link that creates a link between the user and the place. Table (1) shows the different aspects of users' interaction with the environment and their relationship to places.

Table 1. The different aspects of users' interaction with the environment and their connection to different components of the places.

\begin{tabular}{clll}
\hline $\begin{array}{c}\text { Place } \\
\text { Components }\end{array}$ & \multicolumn{1}{c}{$\begin{array}{c}\text { Details of } \\
\text { Relation }\end{array}$} & $\begin{array}{l}\text { Types of } \\
\text { relations }\end{array}$ & \\
\hline Form & $\begin{array}{l}\text { General } \\
\text { perception in } \\
\text { order to } \\
\text { understand the } \\
\text { geometry of }\end{array}$ & Cognitive & $\begin{array}{c}\text { Interaction } \\
\text { between users } \\
\text { \& places }\end{array}$ \\
& $\begin{array}{c} \\
\text { space and } \\
\text { orientation }\end{array}$ & \\
\hline Function & $\begin{array}{l}\text { Perception of } \\
\text { space capabilities } \\
\text { to obviate the } \\
\text { needs }\end{array}$ & Behavioral & \\
\hline Meaning & $\begin{array}{l}\text { Perception of } \\
\text { satisfaction and } \\
\text { attachment to } \\
\text { place }\end{array}$ & $\begin{array}{l}\text { Sense of } \\
\text { belonging }\end{array}$ \\
& & \\
\hline
\end{tabular}

Source: Altman- I. \&Low- S. (1992), Human behavior and environments: Advances in theory and research. V. 12, Place attachment, New York.

Shamai (1991) has defined measures of place and showing the interaction between place and user. In addition to the meanings that distinguish it from others. Which is Coalesce with purposes of place through continuity and consistency of the user with 
the place. Also, Being in a place, which is linked to the actual behavior of users in the place. Moreover, Sacrifice to place, which considered the highest level.[28]

"Sense of place" is a concept for building communication between the place and users. This is achieved by understanding daily activities, icons, their meanings, and creating a sense of belonging to the place. Individual and societal values influence the sense of place, which also affects users' behavior, values, attitudes, and social activities. A sense of place is the relationship between a user, his personality, and the environmental characteristics, See Fig 2. This plays an important role in the

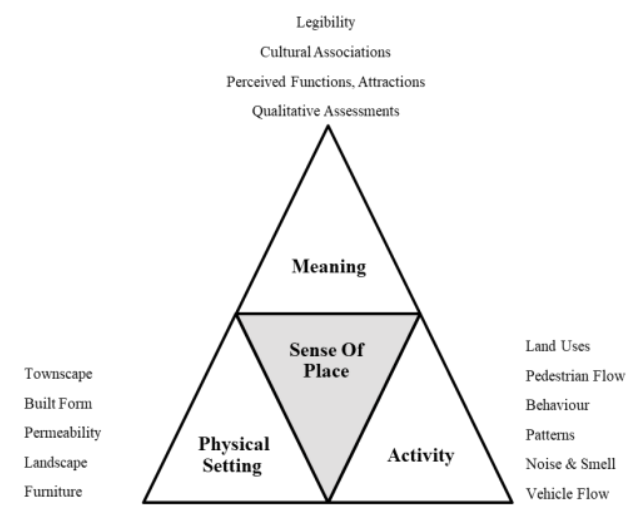

Fig 2. The model "sense of place" of "John Panter" is referring to the components involved in creating a sense of place.

variation of attachment to place. [17]

Therefore, the relationship between the user and the place is mutual. As users make different meanings, positive or negative, about the places and give them meaning. According to Steele (1981), the sense of place is the experience of everything users carry to places [30]. Jorgensen (2001) defined the dimensions of the place: The emotional, behavioral, and functional dimensions. The emotional dimension means the feelings of users, the behavioral dimension resulting from knowledge dimension of users. And, the functional dimension of the place that must fit into the behavioral and emotional dimension. [22]

As it clears from the above that, in urban design the definition of place is a combination of user and of different activities. It creates a feeling which differs from a user to anothers in satisfaction, desire, needs, identity, and attachment to local communities.

\section{The difference between Space\& place}

There is a need to clarify the space and place discussed by philosophers and Geographers because of the confusion between the two concepts. Cresswell (2004) defined the space as an abstract term used to measure geometric spaces and volumes. While he defined the place represents the range of activities that people do, the opportunities for them, and the meanings they give to it [13].

On the other hand, Leibniz (1981) defines the concept of space as a system of relationships between existing physical elements that can be seen and can be measured. While he defined place as the relationship between physical material and nonphysical components [36]. While Heidegger (1973) considered the space to be an existential reality, it is a social product that is constantly being created. When space acquires the meaning of the user, it becomes a place. Places are a source of identity formation for their users through the social, emotional, and psychological relationships that arise between them [24]. Ralph (1976) asserted that the place is the space experienced by humans. Therefore, the social interaction that arises in the place creates an identity that distinguishes it from others [26]. Casey (2000) stated that places leave an impact on users' souls and memory through social interactions that occur within them [10].

\section{Results}

From the above, we deduce the concept of both space and place in urban design science. The urban space is an engineering area, an abstract term that has no social and cultural connection or value. While the urban place is a site that is created with the aim of human improvements such as social or cultural values that are full of different human experiences. The shape, size, and social characteristics of the urban space are important. Physical characteristics are formed due to the relationship between users and their environment. So, it's important because they affect human beings. However, social characteristics are important too because they meet the needs of different users and make urban place-effective. Thus, the general urban space is the piece of land that everyone can access - that is, not owned by a particular person. While the general urban place is the land that has meaning, its own identity. 
Therefore, there is a need to assess the relationships that people have with urban places. The urban place is user experiences and social interaction. In other words, when a group of people connects a certain space with their personal experiences, cultural values, and social meanings, it becomes their place. The urban place is an environment for social interaction to build a daily routine of economic and social life; and has daily experiences. It is also a site of social and cultural values that reflect local identity.

On the other hand, the urban space is not a condition that changes over time, unlike the urban place. It is required to change over time because the user's needs and social and cultural values change over time. These values change over time due to various factors such as economic, technology, and politics. As a result, it is reshaping urban places.

The space and place in urban design science can be distinguished through social and cultural dimensions. They determine the quality of social relationships between users and are built on different aspects of space and place.

Place-makers have differentiated the concept of space and place to explain the concept of placemaking. 'Empty' or 'lifeless ' physical space is transformed into something 'lived' through the presence of people and their interactions with each other as they are engaged in making it a place. The following table summarizes the difference between space and place:

Table 2. The table shows the difference between space and place

\begin{tabular}{|c|c|c|}
\hline & Space & Place \\
\hline Definition & $\begin{array}{l}\text { is an engineering } \\
\text { area, an abstract } \\
\text { term that has no } \\
\text { social and cultural } \\
\text { connection or value }\end{array}$ & $\begin{array}{l}\text { is a site that is } \\
\text { created with the } \\
\text { aim of human } \\
\text { improvements } \\
\text { such as social or } \\
\text { cultural values } \\
\text { that are full of } \\
\text { different human } \\
\text { experiences. }\end{array}$ \\
\hline $\begin{array}{l}\text { Urban or } \\
\text { architectural }\end{array}$ & can be both. & can be both \\
\hline Activities & $\begin{array}{l}\text { Does not contain } \\
\text { activities, and if it } \\
\text { contains activities it } \\
\text { becomes a place. }\end{array}$ & $\begin{array}{l}\text { The place can be } \\
\text { limited to one or } \\
\text { multiple } \\
\text { activities. It is a } \\
\text { multi-use multi- }\end{array}$ \\
\hline
\end{tabular}

\begin{tabular}{|c|c|c|}
\hline & & use place \\
\hline Components & $\begin{array}{l}\text { The space is made } \\
\text { of hardware such as } \\
\text { walls, floors, } \\
\text { ceilings, natural } \\
\text { elements, furniture } \\
\text { and other esthetic } \\
\text { details. It may not } \\
\text { contain } \\
\text { components. }\end{array}$ & $\begin{array}{l}\text { The place consists } \\
\text { of hardware, non- } \\
\text { physical } \\
\text { components such } \\
\text { as social } \\
\text { activities, values, } \\
\text { meanings, and } \\
\text { symbolism } \\
\text { associated with } \\
\text { the community of } \\
\text { the place. }\end{array}$ \\
\hline $\begin{array}{l}\text { Relationship } \\
\text { to time }\end{array}$ & $\begin{array}{l}\text { It does not change } \\
\text { over time. }\end{array}$ & $\begin{array}{l}\text { The place is } \\
\text { changed over } \\
\text { time, according to } \\
\text { the needs and } \\
\text { requirements of } \\
\text { its users, and in } \\
\text { accordance with } \\
\text { their local culture. }\end{array}$ \\
\hline $\begin{array}{l}\text { Relationship } \\
\text { to the } \\
\text { environment }\end{array}$ & $\begin{array}{l}\text { Not affected by } \\
\text { changing the urban } \\
\text { environment. }\end{array}$ & $\begin{array}{l}\text { It is influenced by } \\
\text { changing the } \\
\text { urban } \\
\text { environment, } \\
\text { where it is } \\
\text { influenced by the } \\
\text { culture of its } \\
\text { users. }\end{array}$ \\
\hline $\begin{array}{l}\text { Success } \\
\text { scale }\end{array}$ & $\begin{array}{l}\text { Planning and land } \\
\text { exploitation \& } \\
\text { distribution of their } \\
\text { services in a } \\
\text { manner } \\
\text { commensurate with } \\
\text { the needs of users, } \\
\text { not only the } \\
\text { personal interests } \\
\text { of the State. }\end{array}$ & $\begin{array}{l}\text { Meet the needs } \\
\text { and desires of } \\
\text { users, and reach } \\
\text { out to visitors and } \\
\text { users, and return } \\
\text { to the place. }\end{array}$ \\
\hline
\end{tabular}

Source: The author.

\section{References}

[1] A. John, "Space-place: In P. Cloke \& R. Johnston (eds.), Spaces of geographical", 2004.

[2] A. Majeed, "The Theory of Place in the Philosophy of Avicenna", Review and Presentation: Dr. Abdul-Amir AlAsam, Iraq, 1987.

[3] A. Irwin, "Human Behavior and Environments", Advances in Theory and Research. V. 12, Place attachment ,New York, 1992.

[4] A. Ash, "Collective Culture and Urban Public SpaceInitiative of the Woodrow Wilson International the Center for Scholars", The Development Bank of Southern Africa and the CCCB, France, 2006.

[5] A. Luis, "Frechet and the Logic of the Constitution of Abstract Spaces from Concrete Reality", Colombia, 1999. 
[6] Aristotle, "The Works of Aristotle the Famous Philosopher", US, 2013.

[7] B. Thomas, "Place Versus Space: From Points, Lines and Polygons in GIS to Place-Based Representations Reflecting Language and Culture", Research Paper on University of Salzburg, Australia, 2018.

[8] C. David, "The Facets Of Place: Advances in Environment", Behavior and Design, Research, and Utilization, New York, 1997.

[9] C. Matthew, H. Tim, O. Toner \& T. Steven, "Public Places", Spring Street, New York, US, 2003.

[10] C. Edward, "Place Memory: Remembering", A Phenomenological Study on Indiana University Press, Bloomington, 2000.

[11] C. Helen, "Geography's Inner Worlds: Pervasive themes in Contemporary American Geography”, US, 1992.

[12] C. Tim, "The Place", Researcgh Paper on University of London, UK, 2009.

[13] C. Tim, "Place: A Short Introduction", Oxford: Blackwell, UK, 2004

[14] D. Christian, "Renegotiating Public Space", Research Paper on The University of Tokyo, Japan, 2008.

[15] D. Fabio, "Space, Place and Territory", US, 2017.

[16] E. Schumacher, "A Guide for the Perplexed", US, 1977.

[17] F. Jennifer, K. Linda, "Sense of Place In Natural Resource Recreation and Tourism: An Evaluation and Assessment of Research Findings", Research Paper on Pacific Northwest Research Station, Portland, 2005.

[18] H. Imad , "Strategies for Developing Urban Public Spaces", Master Thesis on Islamic University of Gaza, Palestine, 2015.

[19] H. Hashem, H. Ali \& H. Parisa, "Sense of Place and Place Attachment", Research Paper on Iran University of Science and Technology, Iran, 2012.

[20] H. Ashild, "Identity and Place: A Critical Comparison of Three Identity Theories", Article on Architectural Science Review, October 2008. Available from: http://www.highbeam.com, last accessed: October 20, 2008.

[21] Ibn Khaldun, "Introduction to Ibn Khaldun", Edited by Khalil Shahada, Beirut, 2001

[22] J. Bradley \& S. Richard, "Sense of Place as an Attachment: Lakeshore Owners Attitudes Toward their Properties", Research Paper on University of Bath, UK, 2001.

[23] Lefebvre, "The Production of Space", Blackwell, Oxford, 1991.

[24] M. Helder \& A. Catarina, "Space \& Place in Urban Cultural", Esmae politecnico do porto, Portugal, 2014.

[25] M. Babiano , "Fundamentals of Placemaking for the Built Environment", Australia, 2020.

[26] Relph, "Place and Placelessness", Pion Limited, London, 1976.

[27] Schulz, "Meaning in Western Architecture", London, 1974

[28] S.Shamai, "Sense of Place: An Empirical Measurement", Geoforum, 1991.

[29] S. Farzad \& M. Atefeh, "Study of Characteristics of Urban Public Open Spaces Based on Social Interaction", Research Paper on Islamic Azad University, Iran, 2015.

[30] Steele, "The sense of place", CBI Publishing Company, US, 1981.

[31] S. Amy, "Placemaking and Communities: A Review of Concepts, Indicators, Policy and Practice", The Research Agency of the Forestry Commission, UK, 2010.

[32] Tuan, "Space and Place: The Perspective of Experience", Edward Arnold, London, 1977.

[33] Tuan, "Space and Place The Perspective of Experience", Research Paper on University of Minnesota Press, US, 2001.

[34] Un- Habitat, "Street as Public Space \& Drivers of Urban", Nairobi, Kenya, 2013.

[35] Un-Habitat, "Issue Paper in Public Space", New York, US, 2015.
[36] Yohn, "Durero's Drawing Network as a Model for a Reflection on Sculpture", Editorial Service of the University of the Basque Country, Spain, 2000. 